\title{
Chaetopterus antarcticus (Polychaeta: Chaetopteridae) in Argentinian shelf scallop beds: from infaunal to epifaunal life habits
}

\author{
Claudia S. Bremec ${ }^{1} \&$ Laura Schejter ${ }^{1,2}$ \\ 1. Instituto de Investigaciones Marinas y Costeras, Consejo Nacional de Investigaciones Científicas y Técnicas (IIMyC- \\ CONICET), Argentina; claudiasilviabremec@gmail.com \\ 2. Instituto Nacional de Investigación y Desarrollo Pesquero (INIDEP). Paseo Victoria Ocampo $\mathrm{N}^{\circ} 1,7600$, Mar del \\ Plata, Argentina; schejter@inidep.edu.ar
}

\author{
Received 13-VII-2018. Corrected 18-V-2019. Accepted 30-VI-2019
}

\begin{abstract}
Introduction: The shelf-break frontal area in the Argentine Sea, between $37^{\circ} \mathrm{S}$ and $40^{\circ} \mathrm{S}$, is characterized by high frequency and abundance of the parchment worm Chaetopterus antarcticus Kinberg, 1866 associated to Zygochlamys patagonica scallop beds. This polychaete was usually collected within its U tubes, typical of infaunal habit. During 2007, a surprising massive settlement of worms on scallops was observed. Objective: Our objectives is to report the variability of life habits of $C$. antarcticus in scallop grounds distributed between $37^{\circ} \mathrm{S}$ and $40^{\circ} \mathrm{S}$ in Argentinean waters. Methods: The presence of the parchment tube worms on Z. patagonica was analyzed in 892 scallops coming from three samples collected in September (previously obtained for other purposes) and November 2007 and April 2008, between 99-106 m depth in Management Unit $\mathrm{B}\left(16.186 \mathrm{~km}^{2}, 38^{\circ} \mathrm{S}-39^{\circ} 52^{\prime} \mathrm{S}\right)$. Polychaetes were identified and quantified on both valves. In addition, both epibiont and infaunal worms were registered through time. The settlement of C. antarcticus on scallops was monitored during the period 2007-2015 and the presence of free tubes, both empty and inhabited by worms, were registered during the period 2008-2015 from a total of 374 representative subsamples (10 1) collected with trawling tools between $37^{\circ} \mathrm{S}$ and $40^{\circ} \mathrm{S}$. Results: Scallops collected in 2007 and 2008 showed that $468(>50 \%)$ specimens were encrusted; in $66 \%$ (311 specimens) of them C. antarcticus was settled. The temporal analysis showed that the spatial distribution of epibiotic worms decreased in 2009, 2010 and 2012, with its total absence in 2013, 2014 and 2015 in the study area. During the period 2007 - 2015, infaunal worms were registered throughout the area, collected in part of the locations monitored. Conclusions: The variability of life habits of $C$. antarcticus was not commonly registered previously in the study area; epibiotic behavior could be the result of intensive soft sediment disturbance due to trawling and hence, the selection of other available primary settlement substrate.
\end{abstract}

Key words: chaetopterid, sandy bottom, scallop beds, infaunal, epifaunal, Argentina.

Bremec, C. S., \& Schejter, L. (2019). Chaetopterus antarcticus (Polychaeta: Chaetopteridae) in Argentinian shelf scallop beds: from infaunal to epifaunal life habits. Revista de Biología Tropical, 67(S5) Suplemento, S39-S50.

The shelf-break frontal area in the Argentine Sea is one of the most productive ecosystems in the southwest (SW) Atlantic Ocean (Acha, Mianzan, Guerrero, Favero, \& Bava, 2004). It is characterized by the presence of extensive beds of the Patagonian scallop Zygochlamys patagonica (King, 1832), a pectinid species exploited by scallopers since 1996 and distributed between $37^{\circ} \mathrm{S}-47^{\circ} \mathrm{S}$ along the $100 \mathrm{~m}$ isobath (Lasta \& Bremec, 1998; Schejter, Bremec, Escolar \& Giberto, 2017). This commercial resource and the invertebrate by-catch are yearly monitored as part of the scallop management plan. Early research on composition 
and structure of the by-catch in the spatial and temporal scales (Bremec \& Lasta, 2002; Bremec et al., 2008; Escolar, Diez, Hernandez, Campodónico, \& Bremec, 2009; Escolar, Hernández, \& Bremec, 2011; Mauna, Acha, Lasta, \& Iribarne, 2011; Schejter et al., 2012; Schejter, Bremec, Escolar \& Giberto, 2017), production and trophic interactions (Bremec, Brey, Lasta, Valero, \& Lucifora, 2000; Schejter, Bremec, Akselman, Hernandez, \& Spivak, 2002; Botto et al., 2006; Souto, 2009) showed the high frequency and abundance of the parchment worm Chaetopterus antarcticus Kinberg, 1866 (see Moore, Nishi, \& Rouse, 2017) between $37^{\circ} \mathrm{S}$ and $40^{\circ} \mathrm{S}$, associated to the commercial scallop. This polychaete was usually collected within its free U tubes, typical of infaunal habit (see Rouse, 2001; Nishi, Hickman, \& Bailey-Brock, 2009) (Fig. 1).

However, the yearly assessment of invertebrate by-catch of the scallop fishery conducted during November 2007 monitoring cruises (Bremec, Marecos, Schejter, Escolar, $\&$ Souto, 2008) showed notorious settlement of parchment worms on Z. patagonica. Previous works on Z. patagonica epibionts (Diehl, 1977; Walossek, 1991; Rosso \& Sanfilippo, 1991; Sanfilippo, 1994; Bremec \& Lasta, 2002; Bremec, Marecos, Schejter, \& Lasta, 2003) mentioned organisms like calcareous algae, poriferans, hydrozoans, anthozoans, polychaetes, molluscs, cirripeds, foraminiferans, ascidians and bryozoans, without records of Chaetopterus as one of the worms. In general, during the period 1995-2006, 10 years since the start of the fishery (Bremec \& Lasta, 2002; Bremec, Schejter, \& Marecos, 2006), yearly sampling showed that the polychaetes that heavily encrusted scallops in all the fishing grounds were tube worms of the families Sabellariidae, Sabellidae and Serpulidae (Idantyrsus macropaleus (Schmarda, 1861), Potamilla antarctica (Kinberg, 1866) and Serpula narconensis Baird, 1865 respectively) (Bremec et al., 2006), in agreement with the research about polychaetes in the Argentinean shelf from extensive samplings during R/V Shinkai Maru cruises (Hartmann-Schroeder, 1983; Bremec, Souto, \& Genzano, 2010). Posteriorly, after extensive benthic sampling carried out in 2001 to study richness of taxa encrusting $Z$. patagonica, $4 \%$ of the specimens analyzed resulted basibionts of $C$. antarcticus (Schejter \& Bremec, 2007). In consequence of the surprising settlement of epibiotic worms during 2007, the presence of C. antarcticus on scallops and the spatial distribution of infaunal worms in the study area were analyzed through time, during the period 2007 - 2015. The objectives of this paper are to report variability of life habits of $C$. antarcticus in scallop grounds distributed between $37^{\circ} \mathrm{S}$ and $40^{\circ} \mathrm{S}$ in Argentinean waters.

\section{MATERIALS AND METHODS}

The study area extends between $37^{\circ} \mathrm{S}$ and $40^{\circ} \mathrm{S}$ along the $100 \mathrm{~m}$ isobath in Argentinean waters (Fig. 2). It includes two management

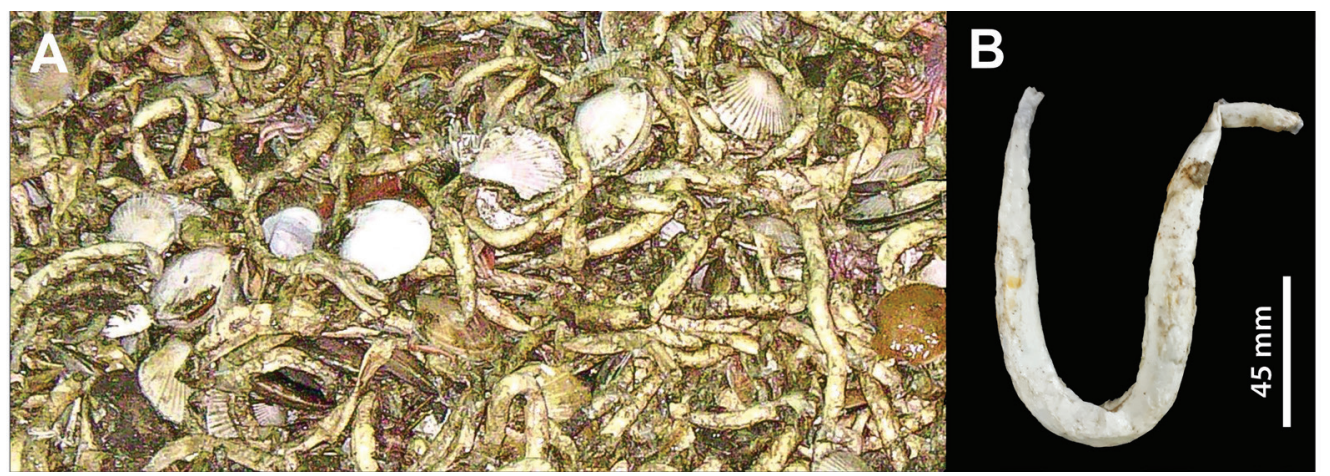

Fig. 1. Free Chaetopterus antarcticus currently collected as associated species in the benthic samples during the period 1995-2006 in scallop beds between $37^{\circ} \mathrm{S}$ and $40^{\circ} \mathrm{S}(\mathrm{A})$. Typical U tube (B). 


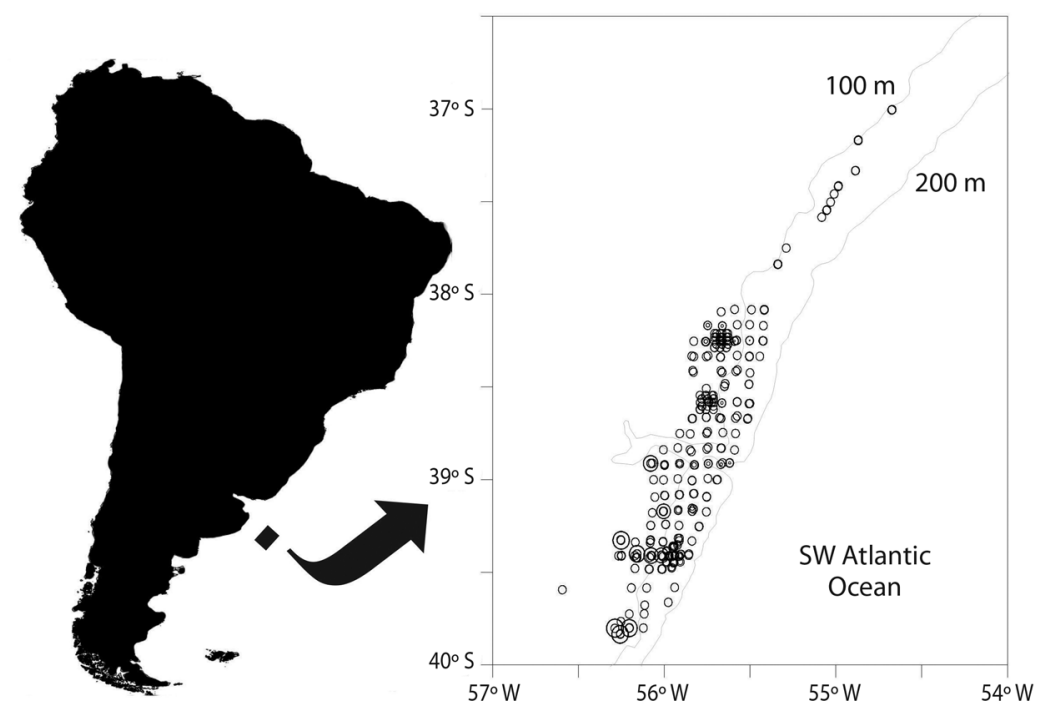

Fig. 2. Location of the samples collected in scallop beds between 2007 and 2015 in the study area (०). Location of samples used to study epibiosis of polychaetes on Patagonian scallops $(\downarrow)$.

units (MU) of the Patagonian scallop (Zygochlamys patagonica) fishery: MU A (7500 $\left.\mathrm{km}^{2}, 37^{\circ} \mathrm{S}-38^{\circ} \mathrm{S}\right)$ and MU B $\left(16.186 \mathrm{~km}^{2}, 38^{\circ}\right.$ S - 39 52' S) (Campodónico \& Mauna, 2014).

The presence of the parchment tube worms on Z. patagonica was analyzed in 892 scallops coming from three samples collected in September (previously obtained for other purposes) and November 2007 and April 2008, between 99-106 m depth in MU B, on board F/V Atlantic Surf I (Figure 2). Polychaetes were identified and quantified on both valves.

In order to explore the dynamics of this behavior in the study area, between $37^{\circ} \mathrm{S}$ and $40^{\circ} \mathrm{S}$, both epibiont and infaunal worms were registered through time. The settlement of Chaetopterus antarcticus on scallops was monitored during the period 2007-2015 and the presence of free tubes, both empty and inhabited by worms, were registered during the period 2008-2015. The number of sites sampled during the study period, with and without living worms, is shown in Table 1. Information includes the general composition of epifaunal benthos in the area: relative wet weight of invertebrate by-catch (i.e. without scallops) and chaetopterid tubes and the relative abundance of inhabited tubes $\left(\mathrm{N}^{\mathrm{o}}\right.$ individuals $\left./ 100 \mathrm{~m}^{2}\right)$. It

TABLE 1

Number of sampling stations and general composition of the benthic samples collected during the study period 2007-2015 between $37^{\circ} \mathrm{S}-40^{\circ} \mathrm{S}$, Argentine Sea. The relative percentages (wet weight) of associated invertebrates (not scallops) in the total sampling, Chaetopterus antarcticus total tubes (inhabited+empty) related with invertebrates and C. antarcticus empty tubes related with total tubes are shown. During 2007 sampling inhabited and empty tubes were not computed

\begin{tabular}{lcccccccc} 
& 2007 & 2008 & 2009 & 2010 & 2012 & 2013 & 2014 & 2015 \\
\% invertebrates & 62,17 & 56,99 & 65,52 & 53,23 & 56,20 & 55,25 & 59,21 & 52,25 \\
\% total tubes & 24,90 & 30,90 & 17,95 & 9,32 & 9,11 & 23,37 & 25,86 & 9,74 \\
\% empty tubes & - & 39,95 & 0,04 & 3,25 & 1,35 & 4,07 & 25,52 & 55,93 \\
$\mathrm{~N}^{\circ}$ st. sampled & 88 & 92 & 34 & 34 & 24 & 35 & 30 & 37 \\
$\mathrm{~N}^{\circ}$ st. inhabited tubes & - & 31 & 29 & 22 & 11 & 13 & 12 & 12 \\
$\mathrm{~N}^{\circ}$ st. empty tubes & - & 46 & 4 & 3 & 5 & 13 & 5 & 14 \\
$\mathrm{~N}^{\circ}$ st. epibiotic C. antarcticus & 25 & 57 & 10 & 9 & 4 & 0 & 0 & 0 \\
\hline
\end{tabular}


was obtained in the context of the Z. patagonica stock assessment and by-catch monitoring program developed by INIDEP, from a total of 374 representative subsamples $(101)$ collected with trawling tools (Figure 2), on board R/V Cap. Cánepa (INIDEP) during 2007 and 2009, F/V Erin Bruce during 2008 and 2012 and F/V Atlantic Surf I during 2010, 2013, 2014 and 2015 (Schejter \& Escolar, 2015; Schejter, Webb, Marecos, \& Escolar, 2015; Schejter, Escolar, Marecos, \& Bastida, 2016).

\section{RESULTS}

The detection of epibiotic Chaetopterus antarcticus occurred after analysis of benthic samples obtained during November 2007 in Patagonian scallop beds. This settlement behavior was registered throughout the study area during 2007 and 2008 (Fig. 3). During 2008 monitoring, the species encrusted $28 \%$ of 4351 commercial scallops (> $55 \mathrm{~mm}$ ) observed throughout the study area. Sampling programs developed during the following years, showed the decrease of the epibiotic behavior of $C$. antarcticus in 2009, 2010 and 2012 and its total absence on scallops collected in 2013, 2014 and 2015 (Fig. 3).

The analysis of 892 scallops collected in 2007 and 2008 to study epibiotic worms (Table $2)$, showed that $468(>50 \%)$ scallops were encrusted; in $66 \%$ (311 specimens) of them $C$. antarcticus was settled. We found 352 worms on upper and 83 worms on lower valves. The position adopted by the worms on lower valves was on the margins, with the chimneys free of attachment. Up to seven worms coexisted on the same upper valve (Fig. 4). Other
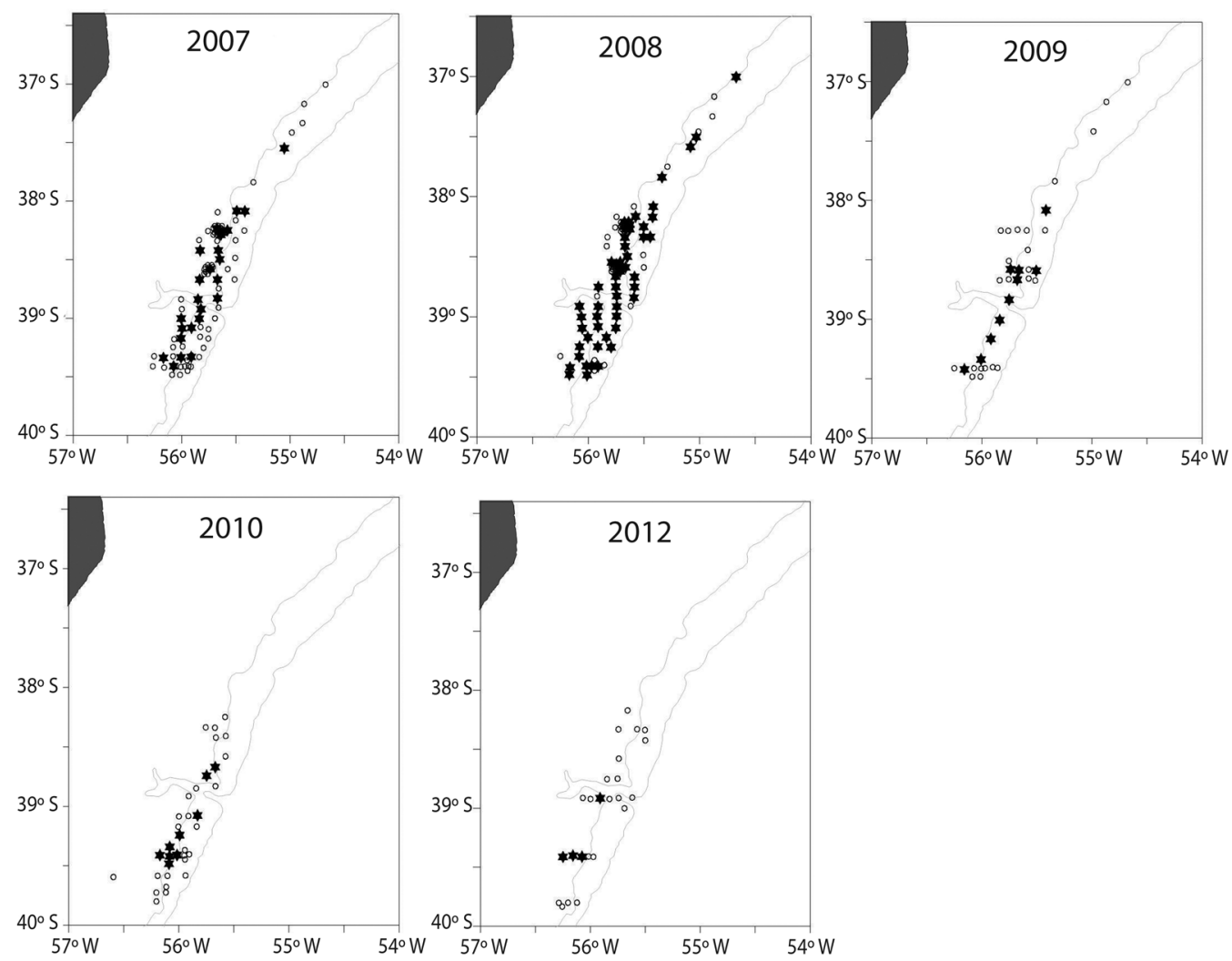

Fig. 3. Location of sampling stations ( $\circ$ ) and spatial distribution of samples (*) with epibiotic Chaetopterus antarcticus between $2007-2012$ in the study area $\left(37^{\circ} \mathrm{S}-40^{\circ} \mathrm{S}\right)$, SW Atlantic. 
TABLE 2

Abundance (number of individuals) of polychaete species encrusting scallops on Upper and Lower valves of Zygochlamys patagonica. Period 2007-2008, 38³7' S - 3909’ S, SW Atlantic

\begin{tabular}{lcccccccc} 
& \multicolumn{2}{c}{ C. antarcticus } & \multicolumn{2}{c}{ I. macropaleus } & \multicolumn{2}{c}{ S. narconensis } & \multicolumn{2}{c}{ P. antarctica } \\
Sampling & $\mathrm{U}$ & $\mathrm{L}$ & $\mathrm{U}$ & $\mathrm{L}$ & $\mathrm{U}$ & $\mathrm{L}$ & $\mathrm{U}$ & $\mathrm{L}$ \\
Sept. 2007 & 269 & 53 & 24 & 1 & 8 & 22 & 2 & 3 \\
Nov. 2007 & 34 & 10 & 10 & - & 2 & 1 & 3 & - \\
April 2008 & 49 & 20 & 47 & - & 3 & 19 & 2 & 5 \\
\hline
\end{tabular}

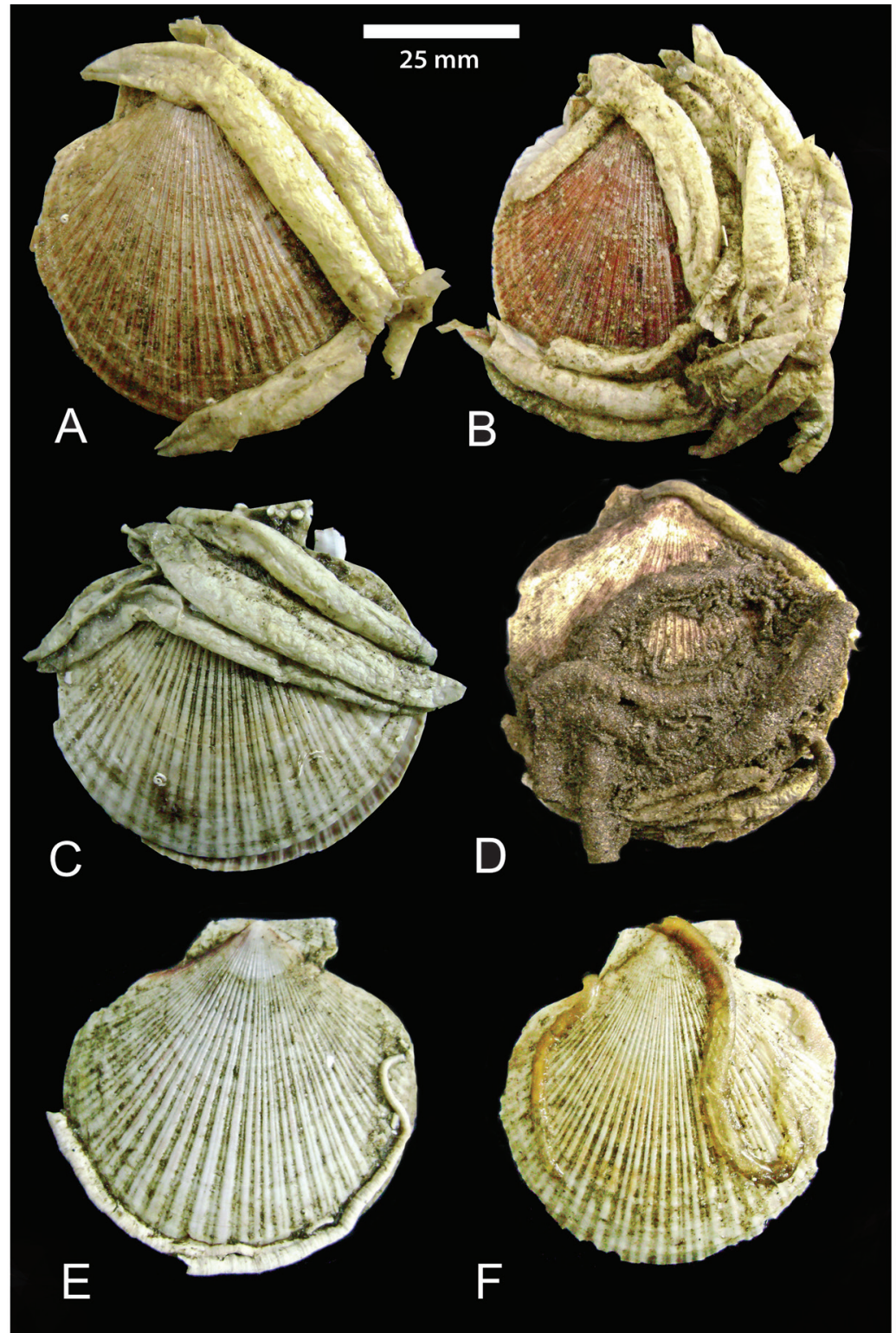

Fig. 4. Tubes of polychaetes settled on Patagonian scallops in the study area ( $\left.37^{\circ} \mathrm{S}-40^{\circ} \mathrm{S}\right)$, SW Atlantic. Chaetopterus antarcticus (A, B, C), Idanthyrsus macropaleus (D), Serpula narconensis (E) and Potamilla antarctica (F). 
conspicuous colonizers were 81 sabellariid worms Idanthyrsus macropaleus, which built sandy tubes on the upper valve. The serpulid Serpula narconensis encrusted auricles and margins, 42 and 13 specimens were found on lower and upper valves respectively. A few individuals of the sabellid Potamilla antarctica, 15 in total, encrusted both valves of scallops (Fig. 4). C. antarcticus was always found on scallops higher than $55 \mathrm{~mm}$, commercial size abundant in the grounds.

The spatial distribution of infaunal worms inside $U$ tubes and empty tubes was assessed during the period 2008 - 2015 (Fig. 5). Infaunal worms were registered throughout the area $\left(37^{\circ} \mathrm{S}-40^{\circ} \mathrm{S}\right)$ during the period 2008-2009. The presence of empty tubes in $50 \%$ of the locations was conspicuous in 2008, as well as a high percentage (wet weight) of empty tubes related with the total tubes (inhabited + empty) (Table 1). Living infaunal worms were collected in part of the locations monitored during the following years, between $38^{\circ} \mathrm{S}-40^{\circ} \mathrm{S}$; empty tubes in more locations and with a relative high proportion during the period 2013 - 2015. Occasional settlement of worms was observed, not quantified, on chondrichthyes capsules during sampling 2008 and on scallop shells during sampling 2012, while empty Chaetopterus tubes were found to be available substrate for a variety of other invertebrates (Fig. 6) (observations of the authors).

\section{DISCUSSION}

An extraordinary settlement of Chaetopterus antarcticus on the Patagonian scallop Zygochlamys patagonica is herein reported. This event was observed during 2007/2008 for the first time, after a decade of sampling in the study area. Previous yearly research on the faunal benthic assemblage where $C$. antarcticus is an associated species, conducted between 1995 and 2006, did not register any massive settlement of the worm on hard substrates (Schejter \& Bremec, 2007; Romero, Schejter, \& Bremec, 2017). Moreover, although Chaetopterus tubes were also recorded in a submarine canyon close
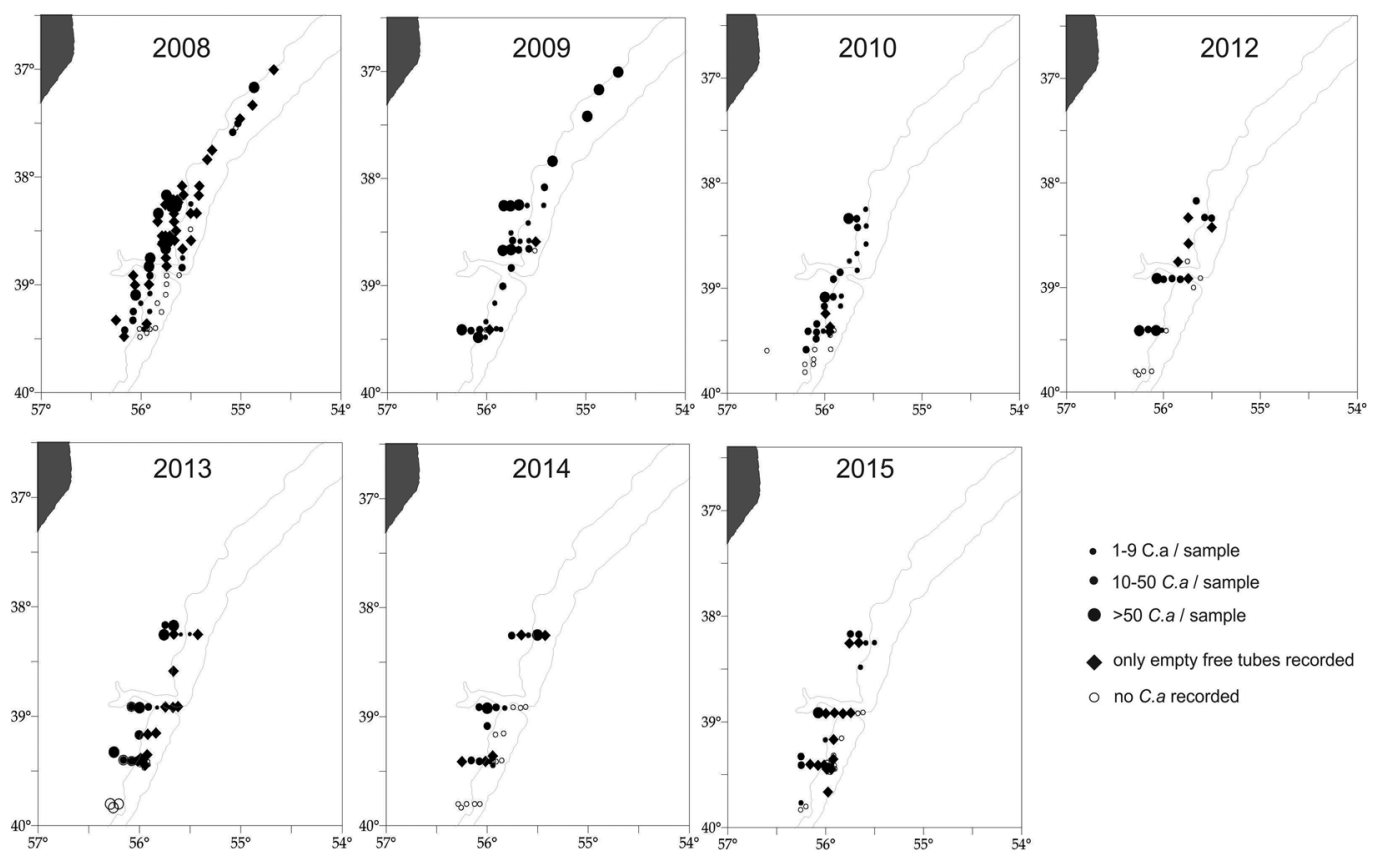

- 1-9 C.a/sample

- 10-50 C.a / sample

- >50 C.a / sample

- only empty free tubes recorded

○ no C.a recorded

Fig. 5. Location of sampling stations (०) and spatial distribution of empty $(\diamond)$ and inhabited $(\bullet)$ tubes of Chaetopterus antarcticus between $2008-2015$ in the study area $\left(37^{\circ} \mathrm{S}-40^{\circ} \mathrm{S}\right)$, SW Atlantic. 


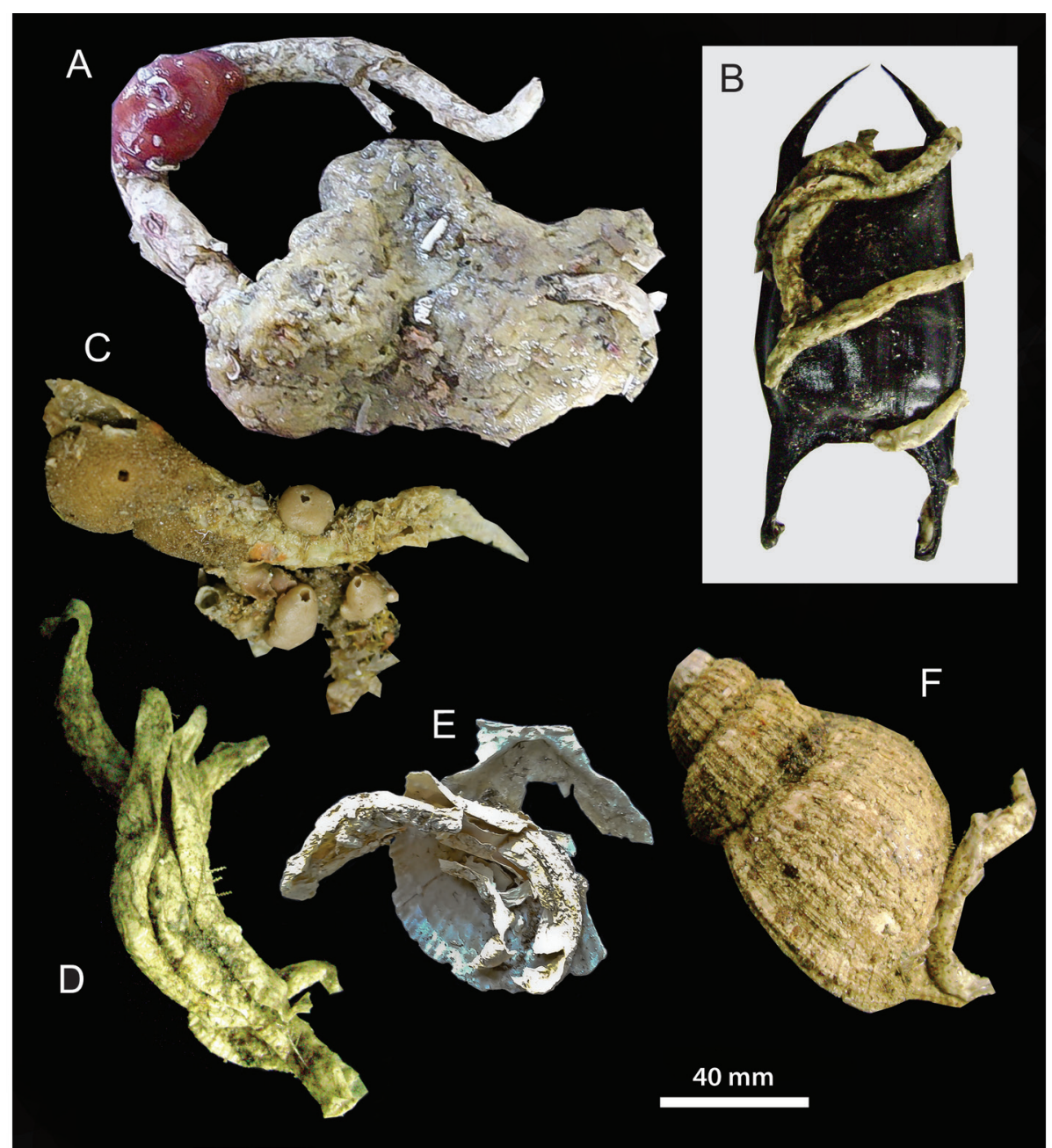

Fig. 6. Empty tubes of Chaetopterus antarcticus with epizoic Porifera and Anthozoa (A, C) and Hydrozoa (D). C. antarcticus settled on chondrichtyes capsule (B), shell of Zygochlamys patagonica (E) and snail (E).

to the scallop beds (Bremec \& Schejter, 2010), also in this deeper and near environment the studied scallops lack this worm in its epibiotic habit (Schejter, López Gappa \& Bremec, 2014). This annelid species was conspicuous, together with the sea star Labidiaster radiosus Lütken, 1871 and the ophiuroid Gorgonocephalus chilensis (Philippi, 1858), and characterized the Patagonian scallop assemblage between $37^{\circ}$ $\mathrm{S}-39^{\circ} \mathrm{S}$, along the $100 \mathrm{~m}$ isobath (Bremec et al., 2008; Schejter, Bremec, Escolar \& Giberto, 2017). After extensive sampling in Argentinean shelf waters developed decades before, it was always registered inhabiting soft bottoms (Hartmann-Schroeder, 1983). Posterior studies about most common epibionts on Z. patagonica based on samples taken in scallop beds $\left(36^{\circ} 20^{\prime} \mathrm{S}-39^{\circ} 00^{\prime} \mathrm{S}\right)$, San Jorge Gulf $\left(45^{\circ} 08^{\prime}\right.$

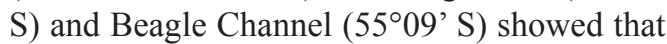
from a total of 256 specimens, $4 \%$ of scallops coming only from Reclutas bed $\left(39^{\circ} 00^{\prime} \mathrm{S}, \mathrm{MU}\right.$ B) was encrusted by Chaetopterus (Schejter \& Bremec, 2007). Conversely, the present results show predominance of $C$. antarcticus settled on scallops, together with the already reported tube worms I. macropaleus, S. narconensis 
and $P$. antarctica in shelf areas (see HartmannSchroeder, 1983; Sanfilippo, 1994; Schejter \& Bremec, 2007; Romero, Schejter \& Bremec, 2017) and deeper waters of a submarine canyon located at $43^{\circ} 13.5^{\prime} \mathrm{S}-59^{\circ} 13.3^{\prime} \mathrm{W}, 325 \mathrm{~m}$ depth (Schejter, López Gappa, \& Bremec, 2014). The majority of individuals were encrusting the upper (left) valves of $Z$. patagonica, sedentary species with limited swimming capacity, in accordance to its morphology (Stanley, 1970). It is presumably developed as escape response in presence of predators, as seen in other pectinid species (see Wilkens, 1991). The most frequent living position adopted by the scallop seems to be with the lower (right) valve in contact with the substrate, as shown by the differential morphology of the valves, being the right ones less concave. The preference of the upper valve, as seen in other epibiotic species, may be related with competitive interactions among epibionts, adaptations to the physical abrasion effects, and/or feeding strategies (Sanfilippo, 1994; Schejter \& Bremec, 2007).

The referred massive epibiotic behavior of the parchment worm was registered in coincidence with huge proportion of empty chaetopterid tubes on the bottom, in half the locations sampled in 2008. During the following years, both infaunal worms in $U$ tubes and empty tubes were collected in variable proportions, while it is clear that the epibioic behavior of $C$. antarcticus decreased dramatically during the study period. Other studies already showed the increment of empty polychaete tubes in areas subjected to trawling activities (Bremec, Giberto, Escolar, Schejter, \& Souto, 2012; Bremec, Schejter, \& Giberto, 2015). Polychaete tubes biomass showed an increase from 1998 to 2002 in fishing grounds located in the present study area, whereas in the reserve zone located within it they were not registered at all in the same period (Schejter, Bremec, \& Hernández, 2008). These polychaete tubes corresponded to the species Chaetopterus antarcticus and Idanthyrsus macropaleus and the increase in their biomass was suggested a consequence of fishing disturbance; Chaetopterus tubes could be removed from the bottom with the nets and could be transported because of the fishery fleet activities or the bottom currents, as well as the detached sandy tubes of Idanthyrsus from the scallop valves. In the case of Chaetopterus tubes, the complex structure-property relations observed indicate that the worm produces such a structure to endure mechanical stresses from specific planes/axes (Shah, Vollrath, Porter, Stires, \& Deheyn, 2014), favoring accumulation of empty resistant tubes on the bottom.

As the extractive activity between 1998 and 2009 was intensive in Patagonian scallop beds, with an increase in the fishing effort in part of the study area in 2007 and 2009 (Escolar, Campodónico, Marecos, \& Schejter, 2015), the chronic trawling could produce removal both of worms inside the tubes and soft sediments, consequently unavailable for infaunal settlement of juvenile worms. In the case of the related species $C$. variopedatus, larvae are planktonic, drifting and feeding in the water column before settling and building a permanent pergamentaceous U-shaped tube buried into the soft bottoms (Fauchald, \& Jumars, 1979; Rouse, 2001). C. antarcticus showed to be successful colonizer of hard substrata, as during 2007-2008, scallops supplied the most important settlement substrate in the study area, although it is characterized by sandy softbottoms, like more than $90 \%$ of the Argentinean continental shelf (Parker, Paterlini, \& Violante, 1997). The sediment type was characterized by fine sands in this area from samples collected between $38^{\circ}-38^{\circ} 30^{\prime} \mathrm{S}$ (Lasta, 2013) and the absence of biogenic substrates was shown by means of multibeam sonar (Madirolas, Isla, Tripode, Alvarez Colombo, \& Cabreira, 2005).

Regarding the presence of free worms during the study period, these results show great variations in the spatial distribution both of inhabited and empty tubes among years. In general, the whole study area was subjected to closures to scallop fishery that covered different areas during different periods of time throughout 2008-2014, ranging between $\sim 8.2$ $\%$ of the management unit during 4 months in 2009 and $\sim 83.3 \%$ during 12 months in 2012 (Campodónico \& Mauna, 2014). Life cycles 
and population dynamics of the majority of the invertebrate species living in the benthic community dominated by the Patagonian scallop are unknown (Bremec \& Echeverría, 2005), and hence, basic knowledge lacks to differentiate between natural and anthropogenic variations. The life span of a related Chaetopterus species in lower Chesapeake Bay showed that few individuals lived $>1 \mathrm{yr}$ during two years period, 1994-1995 (Thompson \& Schaffner, 2001). It is well known that populations of benthic species with planktonic larvae are influenced by a multitude of factors, such as larval transport processes or unpredictable food supply, however, assuming an annual life cycle of $C$. antarcticus, these results are more than expectable and showed a trend already demonstrated worldwide. Trawling fisheries affect marine bottoms and ecosystems in many different, but interrelated, ways, as they produce resuspension of sediments and remove a great number of individuals depending on the gear and type of sediment (Hall, 1999; Collie, Hall, Kaiser, \& Poiner, 2000; Kaiser, Collie, Hall, Jennings, \& Poiner 2002; Hiddink, Jennings, \& Kaiser, 2007; Hinz, Prieto, \& Kaiser, 2009; Clark et al., 2016). Although the aptitude of some chaetopterids to attach tubes to hard substrates was already reported (Bailey-Brock, 1976; Rouse, 2001), the described behavior of C. antarcticus was not commonly registered previously in the study area and constitutes an extraordinary event that, in the present case, could be the result of intensive sediment disturbance, and shows the capacity of adaptation of the species to environmental changes.

Ethical statement: authors declare that they all agree with this publication and made significant contributions; that there is no conflict of interest of any kind; and that we followed all pertinent ethical and legal procedures and requirements. All financial sources are fully and clearly stated in the acknowledgements section. A signed document has been filed in the journal archives.

\section{ACKNOWLEDGEMENTS}

Authors thank scientists, technicians and crews of the stock assessment cruises that participated in sampling procedures, particularly to Ángel Marecos and Mariana Escolar. The comments of two reviewers greatly improved the MS. This is INIDEP Contribution $N^{\circ} 2171$.

\section{RESUMEN}

\author{
Chaetopterus antarcticus (Chaetopteridae) \\ en bancos de vieiras del Atlántico SO: de hábito \\ de vida infaunal a epifaunal
}

Introducción: El área del frente de talud en el Mar Argentino, entre $37^{\circ} \mathrm{S}$ y $40^{\circ} \mathrm{S}$, se caracteriza por alta frecuencia y abundancia del poliqueto Chaetopterus antarcticus Kinberg, 1866 asociado a bancos de vieira Zygochlamys patagonica (King, 1832). Este poliqueto era colectado usualmente habitando los tubos en U, típicos de hábito infaunal. Durante 2007, un sorprendente asentamiento masivo de gusanos sobre vieiras fue observado. Objetivos: Los objetivos del trabajo son reportar la variabilidad del hábito de vida de C. antarcticus en fondos de vieiras entre $37^{\circ} \mathrm{S}$ y $40^{\circ} \mathrm{S}$ en aguas de Argentina. Métodos: La presencia de gusanos tubícolas sobre Z. patagonica se analizó en 892 vieiras colectadas en tres muestras durante Septiembre (muestra tomada con otros propósitos) y Noviembre 2007 y Abril 2008, entre 99-106 m de profundidad en la Unidad de Manejo B $\left(16.186 \mathrm{~km}^{2}, 38^{\circ} \mathrm{S}-39^{\circ}\right.$ 52 ' S). Los poliquetos fueron identificados y cuantificados en ambas valvas. Además, los gusanos tanto epibiontes como infaunales se registraron en un período de tiempo. El asentamiento de $C$. antarcticus sobre vieiras se monitoreó durante 2007-2015 y la presencia de tubos libres, tanto vacíos como habitados por gusanos, durante 2008-2015 a partir de 374 submuestras representativas (10 1) colectadas con artes de arrastre entre $37^{\circ} \mathrm{S}$ y $40^{\circ} \mathrm{S}$. Resultados: Las vieiras colectadas en 2007 y 2008 mostraron que 468 (> 50 $\%)$ especímenes estaban incrustados; $C$. antarcticus estaba asentado en $66 \%$ (311 especímenes) de los mismos. El análisis temporal mostró que la distribución espacial de gusanos epibiontes decreció en 2009, 20101 y 2012, y su ausencia total en 2013, 2014 y 2015 en el área de estudio. Durante el período 2007 - 2015 los gusanos infaunales se registraron en toda el área, en parte de las localidades relevadas. Conclusiones: La variabilidad del hábito de vida de C. antarcticus no había sido registrada previamente en el área de estudio; el comportamiento epibiótico podría ser el resultado del disturbio intensivo de los sedimentos blandos debido al arrastre y en consecuencia, la selección de otro sustrato de asentamiento primario disponible. 
Palabras clave: chaetopterido, fondo arenoso, bancos de vieira, infaunal, epifaunal, Argentina.

\section{REFERENCES}

Acha, E. M., Mianzan, H., Guerrero, R., Favero, M., \& Bava, J. (2004). Marine fronts at the continental shelves of austral South America. Physical and ecological processes. Journal of Marine Systems, 44, 83-105.

Bailey-Brock, J. H. (1976). Habitats of tubicolous polychaetes from the Hawaiian Islands. Pacific Science, 30, 69-81.

Botto, F., Bremec, C., Marecos, A., Schejter, L., Lasta, M., \& Iribarne, O. (2006). Identifying predators of the SW Atlantic Patagonian Scallop Zygochlamys patagonica using stable isotopes. Fisheries Research, $81,45-50$.

Bremec, C., \& Echeverría, A. (2005). Captura incidental de Invertebrados Marinos: revisión bibliográfica sobre ciclos de vida de los taxones. Informe de Investigación INIDEP, 70, 1-23.

Bremec, C., \& Lasta, M. (2002). Epibenthic assemblage associated with scallop (Zygochlamys patagonica) beds in the Argentinian shelf. Bulletin of Marine Science, 70(1), 89-105.

Bremec, C., \& Schejter, L. (2010). Benthic diversity in a submarine canyon in the Argentine sea. Revista Chilena de Historia Natural, 83, 453-7.

Bremec, C., Schejter, L., \& Giberto, D. (2015). Synoptic post fishery structure of invertebrate bycatch associated to Zygochlamys patagonica fishing grounds at SW Atlantic shelf-break front $\left(3^{\circ} \mathrm{S}\right.$, Argentina). Journal of Shellfish Research, 34, 729-736.

Bremec, C., Schejter, L., \& Marecos, A. (2006). Riqueza específica y asociaciones faunísticas en los bancos comerciales de vieira patagónica (Zygochlamys patagonica) a lo largo del frente de talud. Período 19952006. Informe Técnico Interno INIDEP, 106, 1-52.

Bremec, C., Souto, V., \& Genzano, G. (2010). Polychaete assemblages in SW Atlantic: results of "Shinkai Maru" IV, V, X and XI (1978-1979) cruises in Patagonia and Buenos Aires. Anales Instituto Patagonia (Chile), 38, 47-57.

Bremec, C., Marecos, A., Schejter, L., \& Lasta, M. (2003). Guía técnica para la identificación de invertebrados epibentónicos asociados a los bancos de vieira patagónica (Zygochlamys patagonica) en el Mar Argentino. Publicaciones Especiales INIDEP, 1-28.

Bremec, C., Brey, T., Lasta, M., Valero, J., \& Lucifora, L. (2000). Zygochlamys patagonica beds on the Argentinian shelf. Part I: Energy flow through the scallop bed community. Archives of Fisheries Marine Research, 48, 295-303.

Bremec, C., Giberto, D., Escolar, M., Schejter, L., \& Souto, V. (2012). Fauna bentónica asociada a recursos demersales en el área del tratado del Río de la Plata. Resultados de la Campaña de Evaluación EH-04/11. Informe de Investigación INIDEP, 102, 1-12.

Bremec, C., Marecos, A., Schejter, L., Escolar, M., \& Souto, V. (2008). Riqueza específica y asociaciones faunísticas en los bancos comerciales de vieira patagónica (Zygochlamys patagonica) a lo largo del frente de talud. Período 2007. Informe Técnico Oficial INIDEP, 53, 1-29.

Bremec, C., Schejter, L., Giberto, D., Escolar, M, Souto, V., Acha, E. M., \& Mianzan, H. (2008). Benthos of the Argentinean Continental Shelf: faunal assemblages, species distribution and richness along a latitudinal gradient. Book of Abstracts World Conference on Marine Biodiversity 11-15 de Noviembre 2008 (pp. 19). Valencia, Spain: World Conference on Marine Biodiversity.

Campodónico, S., \& Mauna, C. (2014). Vieira patagónica: áreas de exclusión pesquera. Informe de Investigación INIDEP, 29, 1-28.

Clark, M., Althaus, F., Schlacher, T., Williams, A., Bowden, D., \& Rowden, A. (2016). The impacts of deepsea fisheries on benthic communities: a review. ICES Journal of Marine Science, 73(Suppl. 1), i51-i69. doi:10.1093/icesjms/fsv123

Collie, J. S., Hall, S. J., Kaiser, M. J., \& Poiner, I. R. (2000) .A quantitative analysis of fishing impacts on shelfsea benthos. Journal of Animal Ecology, 69, 785-798.

Diehl, M. (1977). Ascidien des Argentinischen Schelfs aus den Grundtrawl-Fängen des FFS "Walther Herwig" auf seiner dritten Südamerika-Expedition. Mitteilungen aus dem Hamburgischen Zoologischen Museum und Institut, 74, 139-153.

Escolar, M., Hernández, D, \& Bremec, C. (2011). Spatial distribution, biomass and size structure of Ctenodiscus australis (Echinodermata: Asteroidea) in shelfbreak areas, Argentine. Marine Biology Research, 7, 608-616.

Escolar, M., Campodónico, S., Marecos, A., \& Schejter, L. (2015). Efecto del arrastre pesquero en la comunidad bentónica asociada a la vieira. Informe de Investigación INIDEP, 84, 1-23.

Escolar, M., Diez, M., Hernandez, D., Campodónico, S., \& Bremec, C. (2009). Invertebrate bycatch in Patagonian scallop fishing grounds: a study case with data obtained by the On Board Observers Program. Revista de Biología Marina y Oceanografia, 44, 369-377. 
Fauchald, K., \& Jumars, P. (1979). The diet of worms: a study of polychaete feeding guilds. Oceanography and Marine Biology Annual Review, 17, 193-284.

Hall, S. J. (1999). The effects of fishing on marine ecosystems and communities. Fish Biology and Aquatic Resources Series, 1, 1-274.

Hartmann-Schroeder, G. (1983). Die Polychaeten der 15., 36. und 76. Reise von FFS "Walther Herwig" zum patagonischen Schelf (Südwest-Atlantik). Senckenbergiana maritime, 15, 251-277.

Hiddink, J. G., Jennings, S., \& Kaiser, M. J. (2007). Assessing and predicting the relative ecological impacts of disturbance on habitats with different sensitivities. Journal of Applied Ecology, 44, 405-413.

Hinz, H., Prieto, V., \& Kaiser, M. (2009). Trawl disturbance on benthic communities: chronic effects and experimental predictions. Ecological Applications, 19, 761-773.

Kaiser, M. J., Collie, J. S., Hall, S. J., Jennings, S., \& Poiner, I. R. (2002). Modification of marine habitats by trawling activities: prognosis and solutions. Fish and Fisheries, 3, 114-136.

Lasta, M. (2013). Bottom sediments. Patagonian scallop (Zygochlamys patagonica) fishery. 1st. Annual Audit, March 11-13, 2013 (1-8 pp.). Mar del Plata, Argentina: INIDEP.

Lasta, M., \& Bremec, C. (1998). Zygochlamys patagonica in the Argentine Sea: A new scallop fishery. Journal of Shelfish Research, 17, 103-111.

Madirolas A., Isla, F.I., Tripode, M., Alvarez Colombo, G., \& Cabreira, A. (2005). First results from the multibeam surveys carried out over the Argentine Continental shelf. Book of Abstracts FEMME Simrad Multibeam Users Conference, Dublin, Ireland, 26-29 April, 2005 (Extended abstract, 2 pp.). Dublin, Ireland: Irish National Seabed Survey.

Mauna, C., Acha, E. M., Lasta, M., \& Iribarne, O. (2011) The influence of a large SW Atlantic shelf-break frontal system on epibenthic community composition, trophic guilds and diversity. Journal of Sea Research, 66, 39-46.

Moore, J., Nishi, E., \& Rouse, G. (2017). Phylogenetic analysis of Chaetopteridae (Annelida). Zoologica Scripta, 46, 596-610.

Nishi, E., Hickman, C., \& Bailey-Brock, J. (2009) Chaetopterus and Mesochaetopterus (Polychaeta: Chaetopteridae) from the Galapagos Islands, with descriptions of four new species. Proceedings of the Academy of Natural Sciences of Philadelphia 158 239-259.

Parker, G., Paterlini, M. C., \& Violante, R. A. (1997). The sea floor. In E. E. Boschi (Ed.). El Mar Argentino y sus Recursos Pesqueros (pp. 65-87). Mar del Plata, Argentina: INIDEP.

Romero, M. V., Schejter, L., \& Bremec, C. (2017). Epibiosis y bioerosión en invertebrados bentónicos marinos. En C. Bremec \& D. Giberto (Eds.). Comunidades bentónicas en regiones de interés pesquero de la Argentina (pp.109-129). Mar del Plata, Argentina: INIDEP.

Rosso, A., \& Sanfilippo, R. (1991). Epibionts distribution pattern of Chlamys patagonica (King and Broderip) of the Magellan Strait. Memorie di Biologia Marina e di Oceanografia, 19: 237-240.

Rouse, G. W. (2001). Chaetopteridae. In G. Rouse, \& F. Pleijel (Eds.). Polychaetes (pp. 256-260). New York, USA: Oxford University Press.

Sanfilippo, R. (1994). Polychaete distribution patterns on Chlamys patagonica of the Magellan Strait. In J.C. Dauvin, I. Laubier, \& D.J Reish (Eds.). Actes de la 4ème Confèrence Internationale des Polychètes Angers France $27^{\text {th. }}$ July $2^{\text {nd. }}$ August 1992. Mémoires du Musséum National d'Histoire Naturelle 162 (pp. 535-540). Paris, France: Éditions du Muséum: Paris.

Schejter, L., \& Bremec, C. (2007). Benthic richness in the Argentine continental shelf: the role of Zygochlamys patagonica (Mollusca, Bivalvia, Pectinidae) as settlement substrate. Journal of the Marine Biological Association of United Kingdom, 87, 917-925.

Schejter, L., \& Escolar, M. (2015). Estudios de riqueza específica en la Unidad de Manejo "B" de la pesquería de vieira patagónica. Informe de Investigación INIDEP, 36, 1-7.

Schejter, L., Bremec, C., \& Hernández, D. (2008). Comparison between disturbed and undisturbed areas of the Patagonian scallop (Zygochlamys patagonica) fishing ground "Reclutas" in the Argentine Sea. Journal of Sea Research, 60, 193-200.

Schejter, L., López Gappa, J., \& Bremec, C. (2014). Epibiotic relationships on Zygochlamys patagonica (Mollusca, Bivalvia, Pectinidae) increase biodiversity in a submarine canyon in Argentina. Deep Sea Research II, 104, 252-258.

Schejter, L., Bremec, C., Escolar, M., \& Giberto, D. (2017). Plataforma externa y talud continental. En C. Bremec \& D. Giberto (Eds.). Comunidades bentónicas en regiones de interés pesquero de la Argentina (pp. 57-75). Mar del Plata, Argentina: INIDEP.

Schejter, L., Escolar, M., Marecos, A., \& Bastida, J. (2016). Fauna asociada a la pesquería de vieira patagónica (Zygochlamys patagónica) en el frente de talud. Monitoreo anual, período 2015. Informe de Investigación INIDEP, 65, 1-14.

Schejter, L., Webb, J., Marecos, A., \& Escolar, M. (2015). Fauna asociada a la pesquería de vieira patagónica 
(Zygochlamys patagónica) en el frente de talud. Monitoreo anual, período 2014. Informe de Investigación INIDEP, 37, 1-14.

Schejter, L., Bremec, C., Akselman, R., Hernandez, D., \& Spivak, E. (2002). Annual feeding cycle of the patagonian scallop Zygochlamys patagonica (King \& Broderip 1832) in Reclutas bed $\left(39^{\circ} \mathrm{S}-55^{\circ} \mathrm{W}\right)$, Argentine Sea. Journal of Shellfish Research, 21, 549-555.

Schejter, L., Escolar, M., Remaggi, C., Alvarez Colombo, G, Ibañez, P., \& Bremec, C. (2012). By-catch composition of the Patagonian scallop fishery: the fishes. Latin American Journal of Aquatic Research, 40, 1094-1099.

Shah, D. U., Vollrath, F., Porter, D., Stires, J., \& Deheyn, D.D. (2014). Housing tubes from the marine worm Chaetopterus sp.: biomaterials with exceptionally broad thermomechanical properties. Journal of the Royal Society Interface, 11, 20140525. http://dx.doi. org/10.1098/rsif.2014.0525

Souto, V. (2009). Estructura y producción de la comunidad de Zygochlamys patagonica en el banco "Reclutas" (39 S) entre los años 1995 y 2006 (Tesis de
Licenciatura). Mar del Plata, Argentina: Universidad Nacional de Mar del Plata.

Stanley, S.M. (1970). Relation of shell form to life habits in the Bivalvia (Mollusca). The Geological Society of America Memoire, 125, 1-296.

Thompson, M., \& Schaffner, L. (2001). Population biology and secondary production of the suspension feeding polychaete Chaetopterus cf. variopedatus: Implications for benthic-pelagic coupling in lower Chesapeake Bay. Limnology and Oceanography, 46, 1899-1907.

Walossek, D. (1991). Chlamys patagonica (King y Broderip, 1832), a long "neglected" species from the shelf of the Patagonian Coast. In S. E. Shumway Ed. An International Compendium of Scallop Biology and Aquaculture (pp. 256-263). Baton Rouge, USA: The National Shellfisheries Association, U S Fish \& Wildlife Service.

Wilkens, L.A. (1991). Neurobiology and behaviour of the scallop. In S. E. Shumway Ed. Scallops: Biology, Ecology and Aquaculture (pp. 429-470). Amsterdam, The Netherlands: Elsevier. 